\title{
Using Aerial Photography for Detecting Blackbrush [Acacia rigidula] on South Texas Rangelands
}

\section{J.H. EVERITT}

\section{Abstract}

Blackbrush (A cacia rigidula) is a native shrub found on a variety of soil types in south Texas and northern Mexico. It often becomes a serious management problem on rangelands, especially where associated species have been removed. During late February to late March it produces small cream to light yellow flowers that encompass the entire plant giving it a conspicuous appearance. Field spectroradiometric plant canopy measurements showed that blackbrush in flower had significantly higher $(p=0.05)$ visible light $(0.45$ to 75-um waveband [WB) reflectance that did 6 other associated plant species or mixtures of species. The conspicuous light yellow color of blackbrush in flower made it distinguishable from other plant species on both conventional color (0.40- to 0.70 -um WB) and color-infrared (CIR) (0.50- to 0.90-um WB) aerial photos. However, conventional color photography was superior to CIR photography because blackbrush had a more distinct image on color photography and it could also be identified on smaller scale photos. Microdensitometric measurements made on conventional color film showed that blackbrush had significantly lower optical counts than those of associated species. These results show that aerial photography may be a useful tool to distinguish blackbrush from other plant species in late winter or early spring to locate its endemic areas, monitor its spread, and delineate areas needing control.

Blackbrush (Acacia rigidula) is a native shrub usually 1 to $3 \mathrm{~m}$ tall that occurs on a variety of soil types in southern Texas and northern Mexico (Correll and Johnston 1970). It may occur in almost pure stands or grow in association with other species in the south Texas mixed-brush complex (Prosopis-Acacia). Although blackbrush has some browse value for white-tailed deer (Odocoileus virginianus) and helps provide wildlife habitat (Davis and Winkler 1968, Everitt and Drawe 1974, McMahan and Inglis 1974), it often becomes a serious management problem on rangelands, especially where associated species have been removed. Blackbrush cannot be controlled by rootplowing or rootplowing followed by raking, and has been known to increase in abundance following burning. Aerial sprays of herbicides offer the most promising control method for blackbrush (Scifres 1980).

During late winter or early spring, blackbrush produces small cream to light yellow flowers that encompass the entire plant giving it a conspicuous light yellow appearance. It was surmised that it may be distinguishable on aerial photographs when it was in its flowering stage. The ability to remotely distinguish blackbrush infestations over large and inaccessible rangeland areas would be beneficial to ranchers and range managers. This information would be useful to monitor its spread and delineate areas needing control. The objective of this study was to test the feasibility of using both conventional color and color-infrared (CIR) aerial photography to distinguish blackbrush when it was flowering from other plant species on south Texas rangelands.

\footnotetext{
Author is range scientist, U.S. Department of Agriculture, Agricultural Research Service, Remote Sensing Research Unit, P.O. Box 267, Weslaco, Texas 78596.

Thanks is extended to R.L. Bowen for obtaining the aerial photography and for producing the illustrations, and to M.A. Alaniz and Gilbert Becerra for their assistance in the field and laboratory.

Manuscript accepted September 24, 1984.
}

\section{Materials and Methods}

Study sites were located on 5 rangeland areas in the Rio Grande Plain resource area of south Texas (Gould 1975). Field spectral measurements were made near La Joya, Texas, in March and July 1983. Aerial photographs and ground truth observations were taken near La Joya, Laredo, Alice, George West, and Tilden, Texas, in March 1983. The La Joya and Tilden sites are approximately $240 \mathrm{~km}$ apart. Additional photos were taken near Laredo in April 1983, and near La Joya in May, July, and September 1983.

Plant canopy reflectance measurements were made in the field on blackbrush, cenizo (Leucophyllum frutescens), honey mesquite (Prosopis glandulosa), lotebush (Ziziphus obtusifolia), Texas persimmon (Diospyros texana), buffelgrass (Cenchrus ciliaris), and mixed grasses and forbs. Cenizo, honey mesquite, lotebush, and Texas persimmon are common woody plant species that occur in association with blackbrush whereas buffelgrass and mixed grasses and forbs are often the dominant herbaceous species. Reflected radiation of 6 randomly selected plant canopies of each species or mixtures of herbaceous species were measured with an Exotech ${ }^{1}$ Model 20 spectroradiometer over the 0.45 - to 0.90 -um waveband (WB) (Leamer et al. 1973). Measurements were made with a sensor that had a 15 -degree field-of-view $\left(0.5 \mathrm{~m}^{2}\right)$ placed $3.0 \mathrm{~m}$ above each plant canopy. Measurements were made under clear sunny conditions between 1100 and $1450 \mathrm{hr}$. To obtain percent reflectance from field spectral data, radiant light is converted into an analog signal in the range of 1 to 5 volts for both incoming and reflected light. Percent reflectance is then calculated by rationing the incoming and reflected light $X$ percent transmission of a diffusing plate. Overhead photographs were taken of the various species and mixtures of species to help interpret canopy reflectance data.

Kodak Aerochrome conventional color (0.40- to 0.70-um WB) type 2448 and color-infrared (CIR) (0.50- to 0.90-um WB) type 2443 films were used for aerial photos. All photos were taken with twin Hasselblad cameras (150 mm lens, $5.7 \times 5.7 \mathrm{~cm}$ format) mounted vertically in the floor of a fixed wing Cessna airplane. For CIR film, the filter packet included Hasselblad $4 \times 0-2$ and $3.5 \times$ CB 12-1.5 filters. The camera had an aperture setting of $f 8$ at $1 / 500$ sec. A clear haze filter was used on the camera containing conventional color film. The camera's aperture was at $\mathrm{f} 11$ with a shutter speed of $1 / 500$ sec. Photos were taken at altitudes of $240,380,460$, 610 , and 760 meters giving photographic scales of $1: 1,600,1: 2,500$, 1:3,000, 1:4,000 and 1:5,000, respectively. Photos were taken near La Joya and Laredo, Texas, 8-10 March 1983 and near Alice, George West, and Tilden, Texas on 16 March 1983. Additional photos were taken near Laredo on 18 April 1983 and near La Joya on 31 May, 7 July, and 2 September 1983. All photos were taken between 1100 and $1400 \mathrm{hr}$ under clear, sunny conditions.

Ground truth reconnaissance was conducted 16 and 17 March 1983 near La Joya and Laredo, Texas, respectively, and on 23 March 1983 near Alice, George West, and Tilden, Texas, for 18 scattered locations where blackbrush was thought to occur after color positive transparencies were viewed on a light table. Ground

\footnotetext{
Mention of company name or trademark is for the reader's benefit and does not constitute endorsement of a particular product by the U.S. Department of Agriculture over others that may be commercially available.
} 
photographs were taken at the various locations to help interpret aerial photographs and observational data were recorded relative to plant species, density, and cover.

Optical density readings were made on conventional color film transparencies with a Joyce Loebl automatic recording microdensitometer (Everitt et al. 1981). The readings were made on film exposed on 9 March 1983 near La Joya, Texas. Film density readings were made with 4 different light sources: white (no filter), red (Wratten 92 filter), green (Wratten 93 filter), and blue (Wratten 94 filter). The microdensitometer output is an optical count (reciprocal of transmission) that is related to optical density (O.D.) by the relation:

$$
\begin{gathered}
\text { O.D. }=[\text { (optical count }- \text { base readings) }(\text { wedge factor })] \\
+(\text { step wedge density }) .
\end{gathered}
$$

One scan line was run for each of 5 plant canopies of blackbrush, cenizo, honey mesquite, mixed brush species, and mixed grasses and forbs on 1:1,600 scale film transparencies. There were 40 to 50 readings (data bits) for each scan line on film. Optical readings were not made around the edges of the transparencies to avoid the effects of lens fall-off. Optical readings were not made on the smaller scale transparencies because many of the selected species" area on film was generally too small to make microdensitometric measurements. Measurements were made on mixed brush canopies because this is typical of brush infestations on rangeland. Optical readings were not made on buffelgrass, lotebush, and Texas persimmon because they could not be distinguished or their area on film was too small to make measurements.

Data were checked for normality and homogeneity prior to statistical analysis. Reflectance data differences among wavelengths were tested using the analysis of variance. Wavelengths selected were $0.55-, 0.65-$, and 0.85 -um, representing, respectively, the green reflectance peak, chlorophyll absorption band, and a wavelength on the near-infrared plateau. Film optical density readings for each colored light were also subjected to analysis of variance. Duncan's multiple range test was used to test the statistical significance at the $0.05 \%$ probability level among species means (Steel and Torrie 1960).

\section{Results and Discussion}

Foliage coloration among the 7 different species or mixtures of species varied greatly in March 1983. Foliage color varied from the silvery-gray cenizo plants to the darker green buffelgrass and lotebush plants. Honey mesquite and Texas persimmon had light green colored foliage. Because of the diversity of species in the mixed grasses and forbs, their colors were different shades of green, and also several of the forbs had various colored flowers. Blackbrush plants had a conspicuous light yellow coloration due to the profusion of flowers. Overhead views of the various species showed that their canopy st ructures also varied. Texas persimmon had greater leaf density and fewer gaps in the canopy than the other species, whereas lotebush and mixed grasses and forbs had more gaps and less leaf density.

Figure 1 shows the field spectroradiometric mean canopy reflectance values over the 0.45 - to 0.90 -um WB for blackbrush and 6 other associated rangeland species or mixtures of species in March 1983. Blackbrush had higher visible $(0.45$ - to 0.75 -um WB) reflectance, and Texas persimmon had higher near-infrared $(0.75-$ to 0.90-um WB) reflectance than the other species. Canopy reflectance values for the 7 species and mixtures of species at 3 wavelengths are given in Table 1. Blackbrush had significantly higher $(p=0.05)$ reflectance at both the 0.55 -um (green reflectance peak) and 0.65 -um (chlorophyll absorption band) visible wavelengths than the other 6 species or mixtures of species. The light yellow flowers of blackbrush apparently contributed greatly to its higher visible reflectance. At the 0.85 -um wavelength, representing the near-infrared (0.75- to 0.90 -um) WB, Texas persimmon had significantly higher $(p=0.05)$ reflectance than the other species. Black-

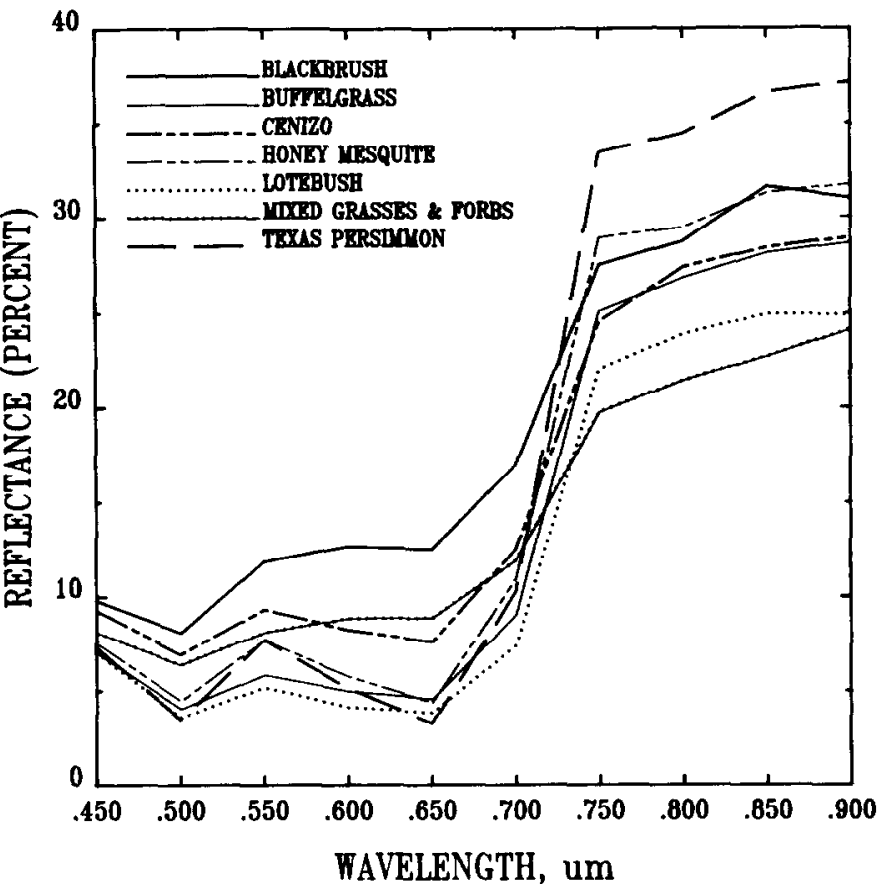

Fig. 1. Field spectroradiometric measured canopy light reflectance over the 0.45- to 0.90-um waveband for blackbrush and six other associated rangeland species or mixtures of species on south Texas rangelands in March 1983 near La Joya, Texas.

brush's near-infrared reflectance did not differ from that of buffelgrass, cenizo, and honey mesquite. The higher near-infrared reflectance of Texas persimmon can probably be attributed to its greater leaf density within the canopy; near-infrared reflectance and vegetation density are positively correlated until a stable reflectance called infinite reflectance is reached (Myers and Allen 1968, Wiegand et al. 1974). However, differences in the near-infrared region may also be attributed to differences in internal leaf structure among the species (Gausman 1974).

Table 1. Mean canopy reflectance of blackbrush and six other rangeland species or mixtures of species in March 1983 for three wavelengths. Field spectroradiometric measurements were taken of six canopies of each species or mixtures of species near La Joya, Texas.

\begin{tabular}{lccc}
\hline \hline \multirow{2}{*}{$\begin{array}{l}\text { Plant species } \\
\text { or mixture }\end{array}$} & \multicolumn{3}{c}{ Wavelengths, um } \\
\cline { 2 - 4 } & $0.55^{\prime}$ & 0.65 & 0.85 \\
\hline Blackbrush & $11.9 \mathrm{a} \pm 0.3^{*}$ & $12.5 \mathrm{a} \pm 0.3$ & $31.6 \mathrm{~b} \pm 1.3$ \\
Buffelgrass & $5.9 \mathrm{~d} \pm 0.3$ & $4.6 \mathrm{~d} \pm 0.4$ & $28.1 \mathrm{bc} \pm 2.0$ \\
Cenizo & $9.3 \mathrm{~b} \pm 0.4$ & $7.6 \mathrm{c} \pm 0.3$ & $28.4 \mathrm{bc} \pm 1.6$ \\
Honey mesquite & $7.7 \mathrm{c} \pm 0.3$ & $4.4 \mathrm{de} \pm 0.2$ & $31.3 \mathrm{~b} \pm 0.8$ \\
Lotebush & $5.2 \mathrm{~d} \pm 0.5$ & $3.8 \mathrm{de} \pm 0.3$ & $24.9 \mathrm{~cd} \pm 2.7$ \\
Mixed grasses and & $8.1 \mathrm{c} \pm 0.5$ & $8.9 \mathrm{~b} \pm 0.7$ & $22.7 \mathrm{~d} \pm 0.6$ \\
$\quad$ forbs & & $3.3 \mathrm{e} \pm 0.2$ & $35.6 \mathrm{a} \pm 1.0$ \\
\hline
\end{tabular}

IValues within columns followed by the same letter do not differ significantly at the $0.05 \%$ level according to Duncan's multiple range test.

* Standard error of mean.

Canopy reflectance values for blackbrush (vegetative stage) and 6 associated plant species or mixtures at 3 wavelengths in July 1983 are given in Table 2 . At the 0.55 - and 0.65 -um visible wavelengths, blackbrush could not be distinguished from lotebush and mixed grasses and forbs, and lotebush, respectively, while at the 0.85-um near-infrared wavelength, blackbrush's reflectance did not differ from that of buffelgrass, lotebush, and mixed grasses and forbs. These data showed that blackbrush in its vegetative stage cannot be distinguished from several associated plant species in either the 
Table 2. Mean canopy reflectance of blackbrush and six other rangeland species or mixtures of species in July 1983 for three wavelengths. Field spectroradiometric measurements were taken of six canopies of each species or mixtures of species near La Joya, Texas.

\begin{tabular}{lccc}
\hline \hline \multirow{2}{*}{$\begin{array}{c}\text { Plant species } \\
\text { or mixture }\end{array}$} & $0.55^{1}$ & 0.65 & 0.85 \\
\cline { 2 - 4 } & $6.1 \mathrm{c} \pm 0.2^{*}$ & $4.8 \mathrm{c} \pm 0.3$ & $24.2 \mathrm{~b} \pm 1.2$ \\
Blackbrush & $7.0 \mathrm{~b} \pm 0.2$ & $6.9 \mathrm{a} \pm 0.4$ & $23.6 \mathrm{~b} \pm 1.1$ \\
Buffelgrass & $8.9 \mathrm{a} \pm 0.4$ & $7.6 \mathrm{a} \pm 0.2$ & $29.1 \mathrm{a} \pm 1.5$ \\
Cenizo & $5.2 \mathrm{~d} \pm 0.2$ & $3.3 \mathrm{~d} \pm 0.2$ & $28.6 \mathrm{a} \pm 0.6$ \\
Honey mesquite & $6.2 \mathrm{c} \pm 0.2$ & $5.2 \mathrm{bc} \pm 0.2$ & $22.4 \mathrm{~b} \pm 0.8$ \\
Lotebush & $6.2 \mathrm{c} \pm 0.3$ & $6.0 \mathrm{~b} \pm 0.1$ & $22.2 \mathrm{~b} \pm 0.6$ \\
Mixed grasses and & & & \\
$\quad$ forbs & $4.7 \mathrm{~d} \pm 0.4$ & $3.2 \mathrm{~d} \pm 0.5$ & $27.5 \mathrm{a} \pm 0.8$ \\
\hline
\end{tabular}

IValues within columns followed by the same letter do not differ significantly at the $0.05 \%$ level according to Duncan's multiple range test.

*Standard error of mean.
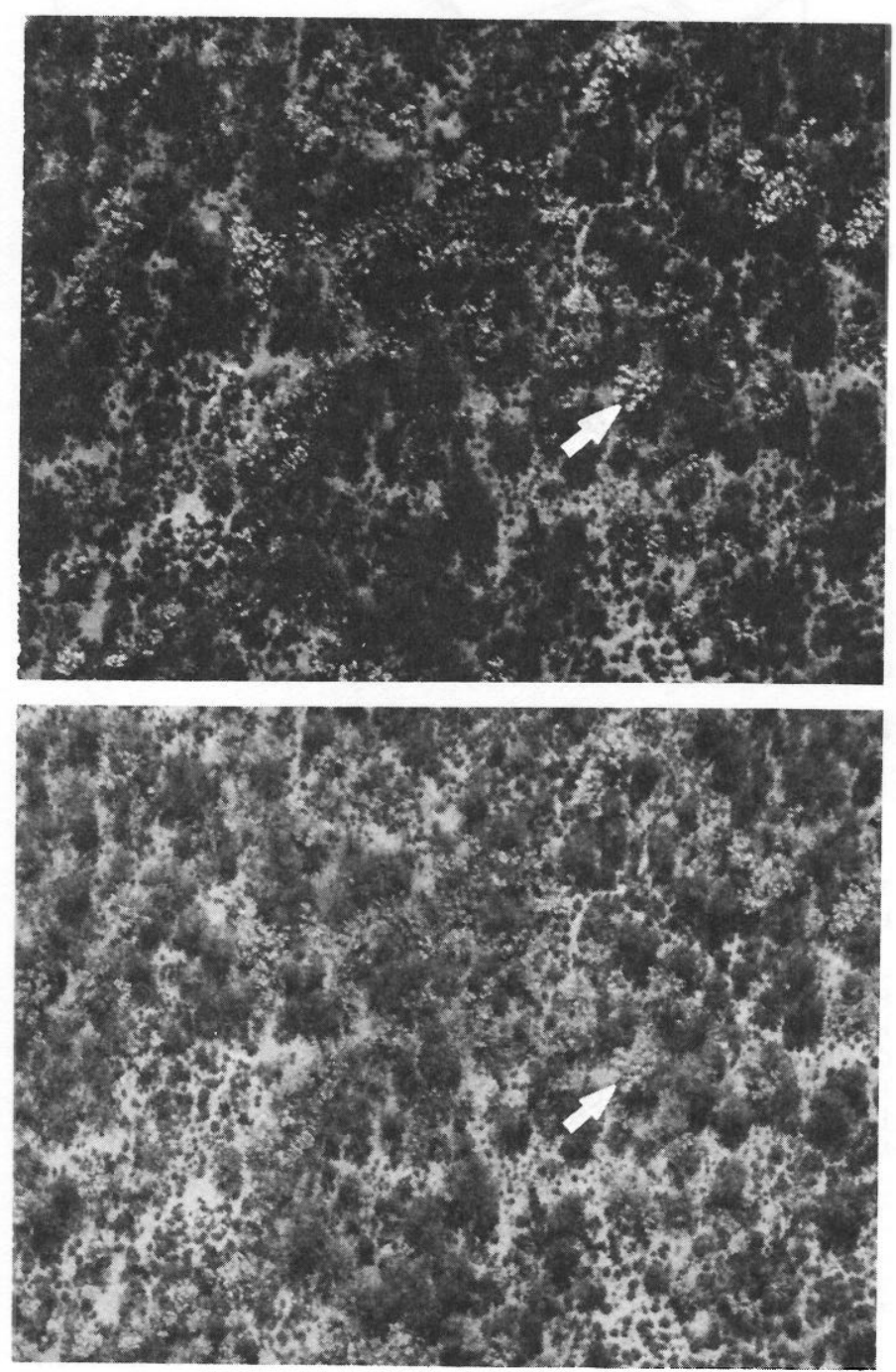

Fig. 2. Upper photograph shows a typical color-infrared (CIR) positive print of blackbrush in a rangeland area near La Joya, Texas. The lower photograph shows a typical conventional color print of the same area. (Both prints are $6 X$ enlargements of original $70-\mathrm{mm}$ photos taken at an original scale of $1: 2,500$.) The arrows on both prints point to blackbrush plants. On the CIR photo it has a whitish image whereas on the conventional color photo it retains its typical light yellow color. visible or near-infrared WB's.

Figure 2 shows typical CIR (upper photo) and conventional (lower photo) positive prints of blackbrush in a rangeland area near La Joya, Texas. Both prints are 6X enlargements of original $70-\mathrm{mm}$ aerial photos (1:2,500 scale) taken on 9 March 1983. Arrows on both prints point to blackbrush plants in flower. Notice that blackbrush is easier to distinguish on the color print because the flowers retain their conspicuous light yellow color. On the CIR photo, the flowers give a more whitish image which makes blackbrush more difficult to distinguish from surrounding soil background. Ground truth reconnaissance in March 1983 for 18 widely scattered sites in south Texas gave $100 \%$ correct identification of blackbrush in its flowering period. Blackbrush could be distinguished from surrounding vegetation on both 1:3,000 and 1:4,000 scale color photos, but on 1:5,000 scale color photos it could not always be delineated. Blackbrush could also be distinguished on 1:3,000 scale CIR photos, but it was not always distinugishable on 1:4,000 scale CIR photos; blackbrush could not be detected on 1:5,000 CIR photos. Blackbrush (vegetative stage) could not be distinguished from surrounding vegetation on either CIR or conventional color photos taken near Laredo on April 18, 1983 or on photos taken near La Joya on 31 May, 7 July, and 3 September 1983. These later photos along with field spectral data taken in July 1983 (Table 2) substantiate that blackbrush's identification on aerial photography is possible only during its flowering period, which generally occurs from late February to late March.

Microdensitometer readings made with either red or green light on 1:1,600 scale conventional color transparencies of a rangeland area near La Joya, Texas, in March 1983 showed that blackbrush had significantly lower $(p=0.05)$ optical counts than those of other associated species or mixtures of species (Table 3). However, opti-

Table 3. Mean microdensitometer (optical) readings with white, red, green, and blue light on aerial conventional color (0.40- to 0.70 -um) film (scale 1:1,600) for blackbrush and four associated plant species or mixtures of species found on south Texas rangelands. Film was exposed on March 9, 1983 near La Joya, Texas.

\begin{tabular}{|c|c|c|c|c|}
\hline \multirow{2}{*}{$\begin{array}{l}\text { Plant species } \\
\text { or mixtures }\end{array}$} & \multicolumn{4}{|c|}{ Optical readings ${ }^{1}$} \\
\hline & White light & Red light & Green light & Blue light \\
\hline Blackbrush & $55 \mathrm{c} \pm 2.2^{*}$ & $36 \mathrm{c} \pm 2.0$ & $41 \mathrm{c} \pm 1.5$ & $63 \mathrm{~b} \pm 1.3$ \\
\hline Cenizo & $59 \mathrm{c} \pm 0.8$ & $58 \mathrm{~b} \pm 0.9$ & $52 \mathrm{~b} \pm 1.4$ & $42 c \pm 1.6$ \\
\hline Honey mesquite & $97 \mathrm{a} \pm 2.4$ & $85 \mathrm{a} \pm 1.0$ & $73 \mathrm{a} \pm 1.5$ & $79 \mathrm{a} \pm 0.8$ \\
\hline Mixed brush & $99 \mathrm{a} \pm 4.2$ & $85 \mathrm{a} \pm 3.2$ & $74 \mathrm{a} \pm 2.1$ & $78 \mathrm{a} \pm 2.5$ \\
\hline $\begin{array}{l}\text { Mixed grasses } \\
\text { and forbs }\end{array}$ & $69 \mathrm{~b} \pm 1.6$ & $59 \mathrm{~b} \pm 1.8$ & $55 \mathrm{~b} \pm 1.2$ & $62 \mathrm{~b} \pm 0.6$ \\
\hline
\end{tabular}

'Mean values within columns followed by a common letter do not differ significantly at the $0.05 \%$ probability level, according to Duncan's multiple range test.

*Standard error of mean.

cal counts made using white or blue light indicated that blackbrush could not be distinguished from associated plant species or mixtures of species. These results are in agreement with the canopy reflectance data shown in Table 1, where blackbrush's reflectance was found to be significantly higher than that of other associated plant species at both the green (0.55-um) and red (0.65-um) wavelengths.

\section{Conclusions}

These results indicate that both conventional color and CIR aerial photographs can be used to delineate blackbrush infestations on south Texas rangelands in late winter or early spring, when this troublesome shrub is in its flowering phenological stage. However, color photography is superior to CIR photography because blackbrush has a more distinct image response on color photography and it can also be detected on smaller scale photos. These findings should be useful to ranchers and range managers to help locate infestations of this plant over large and inaccessible rangeland areas, and to monitor its spread on rangelands. 


\section{Literature Cited}

Correll, D.S., and M.C. Johnston. 1970. Manual of the vascular plants of Texas. Tex. Res. Found., Renner Texas.

Davis, R.B., and C.K. Winkler. 1968. Brush vs. cleared range as deer habitat in southern Texas. J. Wildl. Manage. 32:321-329.

Everitt, J.H., A.H. Gerbermann, and M.A. Alanix. 1981. Microdensitometry to identify saline rangelands on $70-\mathrm{mm}$ color-inf rared aerial film. Photogram. Eng. and Remote Sensing. 47:1357-1362.

Everitt, J.H., and D.L. Drawe. 1974. Spring food habits of white-tailed deer in the south Texas plains. J. Range Manage. 27:15-20.

Gausman, H.W. 1974. Leaf reflectance of near infrared. Photogram. Eng. 40:183-191.

Gould, F.W. 1975. Texas plants. A checklist and ecological summary. Texas Agr. Exp. Sta. MP-585 (Rev.).
Leamer, R.W., V.I. Myers, and L.F. Silva. 1973. A spectroradiometer for field use. Rev. Sci. Instrum. 44:611-614.

McMahan, C.A., and J.M. Inglis. 1974. Use of Rio Grande Plain brush types by white-tailed deer. J. Range Manage. 27:369-374.

Myers, V.1., and W.A. Allen. 1968. Electrooptical remote sensing methods as nondestructive testing and measuring techniques in agriculture. Applied Optics. 7:1818-1838.

Scifres, C.J. 1980. Brush Management. Texas A\&M Univ. Press. College Station, Texas.

Steel, R.G.D., and J.H. Torrie. 1960. Principles and procedures of statistics. McGraw-Hill Book Co., Inc., New York.

Wiegand, C.L., H.W. Gausman, J.A. Cuellar, A.H. Gerbermann, and A.J. Richardson. 1974. Vegetation density deduced from ERTS-I MSS response. Proc. 3rd ERTS-I Symp., Vol. 1, Section A, NASA SP-351. U.S. Govt. Printing Office, Washington, D.C. 